\title{
Intraperitoneal co-administration of thymosin $\alpha-1$ ameliorates streptozotocin-induced pancreatic lesions and diabetes in C57BL/6 mice
}

\author{
LONGXIN QIU $^{1,2}$, CUILIN ZHANG $^{1}$, JUN ZHANG ${ }^{1}$, JIAXIN LIANG ${ }^{1}$, \\ JUN LIU ${ }^{3}$, CISHU JI ${ }^{3}$ and JAMES Y. YANG ${ }^{1,3}$ \\ ${ }^{1}$ Ministry of Education Key Laboratory for Cell Biology and Tumor Cell Engineering and \\ Department of Biomedical Sciences, School of Life Sciences, Xiamen University, Xiamen 361005; \\ ${ }^{2}$ School of Life Sciences, Longyan University, Longyan 364000; ${ }^{3}$ Xiamen University \\ Laboratory Animal Center, Xiamen University, Xiamen 361005, P.R. China
}

Received November 20, 2008; Accepted January 7, 2009

DOI: 10.3892/ijmm_00000169

\begin{abstract}
We investigated the effects of the in vivo administration of thymosin $\alpha-1(\mathrm{~T} \alpha-1)$ on streptozotocin (STZ)-induced pancreatic lesions and diabetes. Mice were randomly divided into four experimental groups: normoglycemic control, STZ-treated, STZ plus $0.1 \mu \mathrm{g} / \mathrm{kg}$ body weight/day T $\alpha$-1-treated, and STZ plus $1 \mu \mathrm{g} / \mathrm{kg} /$ day $\mathrm{T} \alpha-1$ treated. Blood glucose was assayed periodically, and serum insulin was determined at the end of the experiment using the ELISA Kit. Aldehyde fuchsin staining was used for histopathological examination of the pancreas. Parameters for oxidative stress were measured with pancreatic malondialdehyde (MDA) level, glutathione (GSH) content and enzymatic activities of superoxide dismutase and catalase. Fourteen days after the initiation of $\mathrm{T} \alpha-1$ treatment and up to day 35 when the treatment was stopped, both of the two STZ and $\mathrm{T} \alpha-1$-co-treated mouse groups had significant lower levels of blood glucose than the STZ-treated but T $\alpha$-1-untreated mice, although both remained higher than that of the normoglycemic controls. At the end of the T $\alpha-1$ treatment, the serum insulin level for STZ-treated mice receiving $1 \mu \mathrm{g} /$ $\mathrm{kg} /$ day $\mathrm{T} \alpha-1$ for 35 days was 2 -fold $(\mathrm{P}<0.001)$ as much as that of the T $\alpha$-1-untreated STZ-diabetic mice, although not
\end{abstract}

Correspondence to: Dr James Y. Yang, Department of Biomedical Sciences, School of Life Sciences, Xiamen University, Xiamen 361005, P.R. China

E-mail: jyy6127@yahoo.com

Abbreviations: T $\alpha-1$, thymosin $\alpha-1$; TF5, thymosin fraction 5; STZ, streptozotocin; T1DM, type I diabetes mellitus; MDA, malondialdehyde; GSH, reduced glutathione; SOD, superoxide dismutase; CAT, catalase

Key words: thymosin $\alpha-1$, type I diabetes mellitus, oxidative stress, streptozotocin, pancreas, insulin completely restored to the normal level. Pancreatic aldehyde fuchsin staining showed that STZ treatment caused significant pancreatitis, islet atrophy, and a significant reduction in the number of pancreatic $B$ cells. These histological lesions, however, were significantly alleviated by $1 \mu \mathrm{g} / \mathrm{kg} / \mathrm{day} \mathrm{T} \alpha-1$ treatment for 35 days. Furthermore, compared with the T $\alpha-1$ untreated STZ-diabetic mice, the pancreatic GSH level of the $1 \mu \mathrm{g} / \mathrm{kg} /$ day $\mathrm{T} \alpha$-1-treated STZ-induced mice was 1.92 -fold that of the untreated STZ-induced mice $(\mathrm{P}<0.01)$, whereas the pancreatic MDA level was only $81.9 \%$ that of the untreated STZ-diabetic mice $(\mathrm{P}<0.05)$. Together these results demonstrate that co-administration of $\mathrm{T} \alpha-1$ leads to significant protection against STZ-induced pancreatic damage and diabetes, and part of the protection might be achieved through enhancing pancreatic antioxidative capability.

\section{Introduction}

Thymosins are a group of polypeptides that are primarily produced in the thymus gland, the site where $\mathrm{T}$ lymphocytes mature. Initially, these polypeptides were extracted from the thymus of bovine or cow. One of the early crude preparations, thymosin fraction 5 (TF5), contains at least 40 types of small acidic polypeptides, with most having molecular weights ranging from 1-15 kilodaltons. Based on isoelectric focusing, these small polypeptides were classified as $\alpha, \beta$ and $\gamma$ thymosins, respectively. Since their discovery, a great number of studies have been carried out to investigate the distribution, expression regulation, biological function and physiological and pathophysiological roles as well as the clinical usage of these small proteins (1).

Three of the most well-studied thymosins/prothymosins include prothymosin- $\alpha$ (ProT $\alpha$ ), thymosin $\beta 4$ and thymosin $\alpha-1$ $(\mathrm{T} \alpha-1)$. Both ProT $\alpha$ and thymosin $\beta 4$ were initially considered to be thymic hormones but were later found to be widely distributed in many types of mammalian cells. Studies have shown that ProT $\alpha$ is a nuclear protein that plays various important roles such as nucleosome assembly/disassembly, regulation of the cell cycle and apoptosis, nucleocytoplasmic 
transport and the production, processing or export of RNA $(2,3)$. Thymosin $\beta 4$, on the other hand, plays important roles in wound healing and tissue remodeling and has potential use in the treatment of myocardial infarction, chronic pressure ulcers and venostasis ulcer (4).

$\mathrm{T} \alpha-1$ is one of the components of TF5 with diverse potent biological activities (5). The known molecular and biological functions of $\mathrm{T} \alpha-1$ include activation of the p38 MAPK and NFкB pathways, inhibition of steroid-induced thymocyte apoptosis, stimulation of various interleukins and interferons and relevant receptors, regulation of inflammation and immunity, antifungal, bacterial and viral infections. T $\alpha-1$ is a short peptide containing only 28 amino acids, and it can be easily synthesized chemically. T $\alpha-1$ is now approved worldwide in many countries for the treatment of hepatitis B and $\mathrm{C}$ and as immune adjuvant in the treatment of a number of other diseases such as non-small cell lung cancer, melanoma and HIV/AIDS $(6,7)$.

Type I diabetes (T1DM) is largely considered to be a chronic disorder that results from autoimmune destruction of the insulin-producing pancreatic $\beta$ cells. Experimentally, pancreatitis or T1DM models can be easily created by treating mice or rats with pancreatic toxins such as alloxan, STZ or taurocholate. Since thymosins have potent activities against a number of diseases, it is of interest to find out whether they can be beneficial for the protection against the development of T1DM. In 1983, in an effort to investigate whether thymosin administration can boost the immune response to enhance resistance to fungal infections in mice, Salvin and Tanner found that TF5 administration to alloxan-induced diabetic mice significantly improved parameters for resistance to fungal infections (8). In another study, Okimoto et al observed that TF5 treatment in vitro improved the impaired maturation of T lymphocytes from STZ-diabetic mice (9). This TF5mediated $\mathrm{T}$ lymphocyte protection was also further confirmed by Winter et al (10). Of particular interest, however, was that when thymus gland extract TF5 was administered subcutaneously into spontaneous hypertensive rats, blood pressure in the animals was significantly decreased in comparison with the controls (11). Based on changes in mitogen reactivity, rosette formation, prostaglandin E levels, immune complex deposition and blood pressure following TF5 treatment, Strausser (11) suggested that TF5 might be used as an antiautoimmune disease agent, useful in treating autoimmune diseases such as hypertension, lupus and diabetes. Indeed, when TF5 was used to treat STZ-treated CD-1 mice, the induction of insulitis and hyperglycemia was significantly prevented (12). Mizina also reported that thymosin (TF5) treatment restored blood insulin levels to improve blood glucose in alloxan-induced diabetic mice (13). While the above two studies established that TF5 is beneficial for the protection of pancreatic tissues, it is not clear which thymosin plays the major roles since TF5 is a mixture of more than 40 thymic peptides. In a recent study, Yao et al demonstrated that co-administration of $\mathrm{T} \alpha-1$, the first small peptide component isolated from TF5, appeared to improve sodium taurocholate-induced severe acute pancreatitis in rats, based on a few parameters such as changes in peripheral $\mathrm{T}$ cell number and $\mathrm{CD}^{+} / \mathrm{CD}^{+} / \mathrm{CD}^{+}$subtypes as well as serum levels of cytokines including interleukin (IL)-1ß and tumor necrosis factor- $\alpha$ (TNF $\alpha)$ (14). This study suggests that T $\alpha-1$ is beneficial for the protection against chemical toxin-induced pancreatic damage in part through T $\alpha$-1-mediated immunomodulation. In our current study, we aimed to determine whether T $\alpha-1$ is the major molecule responsible for the TF5mediated protection against the development of STZ-induced diabetes in C57BL/6 mice. We also wanted to ascertain whether T $\alpha$-1-mediated antioxidative mechanisms are involved in pancreatic protection.

\section{Materials and methods}

Animal experiments. Male C57BL/6 mice, 6-8 weeks of age, were used for this study. All animals were maintained on standard laboratory chow under a 12 h:12 h light-dark schedule, and experiments were conducted according to protocols and guidelines approved by the Xiamen University Institutional Animal Care and Use Committee. The mice were randomly divided into four experimental groups (each containing 6 animals): normoglycemic control (A), STZtreated (B), STZ + 0.1 $\mu \mathrm{g} / \mathrm{kg} /$ day T $\alpha$-1-co-treated (C), STZ + $1 \mu \mathrm{g} / \mathrm{kg} /$ day $\mathrm{T} \alpha-1$ co-treated (D). Diabetes was induced for $\mathrm{B}, \mathrm{C}$ and D groups of mice by multiple low doses of STZ (Sigma, St. Louis, MO, catalog no. S0130) (40 $\mu \mathrm{g} / \mathrm{kg}$ body weight, intraperitoneal (i.p.) injection once daily for 5 days) administered as a freshly prepared solution in $0.1 \mathrm{mM}$ sodium citrate ( $\mathrm{pH} 4.5$ ). For $\mathrm{C}$ and $\mathrm{D}$ groups of mice, $0.1 \mu \mathrm{g} / \mathrm{kg}$ body weight or $1 \mu \mathrm{g} / \mathrm{kg}$ body weight of $\mathrm{T} \alpha-1$ (Sigma, catalog no. T3410) (dissolved in saline) was co-administered, respectively, as a single daily i.p. injection co-initiated with STZ injection and continued for 5 weeks, after which (day 35) the experiment was terminated. The same volumes of saline were also coadministered to the A and B groups of mice.

Determination of blood glucose and serum insulin. The blood glucose level was measured periodically throughout the experimental period using a glucometer (OneTouch Ultra, LifeScan). At the end of the T $\alpha-1$ treatment, mice were sacrificed, and blood was collected from the sinus orbit. Serum insulin was measured using a mouse insulin enzyme-linked immunoassay kit (ADL, USA).

Determination of superoxide dismutase $(S O D)$ and catalase (CAT) activity. At the end of the experiment, mice were sacrificed. Pancreases were removed quickly, perfused with chilled phosphate buffer (0.1 M, pH 7.4) and stored in liquid nitrogen until use. Tissues were homogenized in cold phosphate buffer $(0.1 \mathrm{M}, \mathrm{pH} 7.4)$ containing $1.17 \% \mathrm{KCl}$ using a Polytron homogenizer. The homogenate was centrifuged at $10,500 \mathrm{x}$ g for $15 \mathrm{~min}$ at $4^{\circ} \mathrm{C}$. The supernatant was used to assay for enzyme activities.

SOD activity was assayed using a commercial kit (Jianchen, Nanjing, P.R. China). Enzyme activity was expressed as units/mg protein, and 1 unit of enzyme was defined as the enzyme activity required for suppressing the production of nitrite by $50 \%$. CAT activity was assayed by following the method of Sinha (15). The reaction mixture (3 ml) contained $1.95 \mathrm{ml}$ of phosphate buffer $(0.1 \mathrm{M}, \mathrm{pH} 7.0)$, $1.0 \mathrm{ml}$ of $0.019 \mathrm{M} \mathrm{H}_{2} \mathrm{O}_{2}$, and $0.05 \mathrm{ml}$ of tissue homogenate (supernatant). Changes in absorbance were recorded at $240 \mathrm{~nm}$ 
a

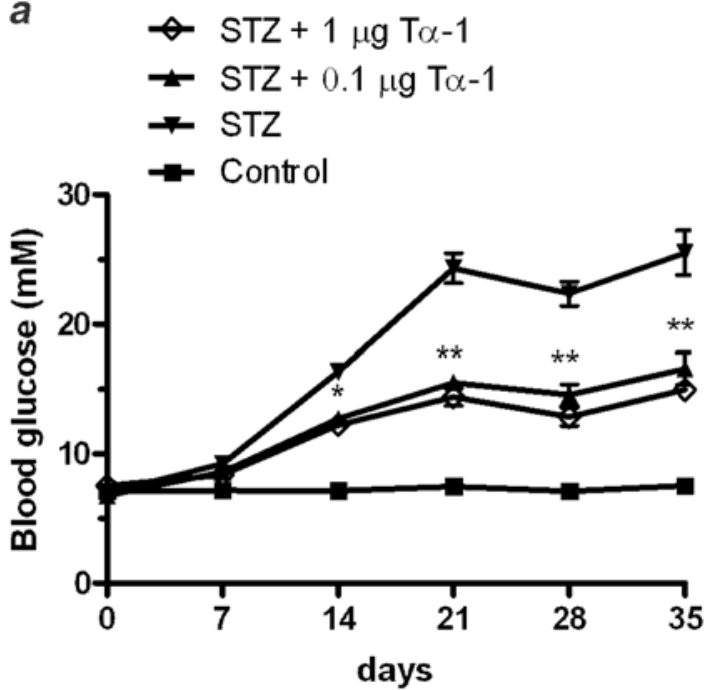

b

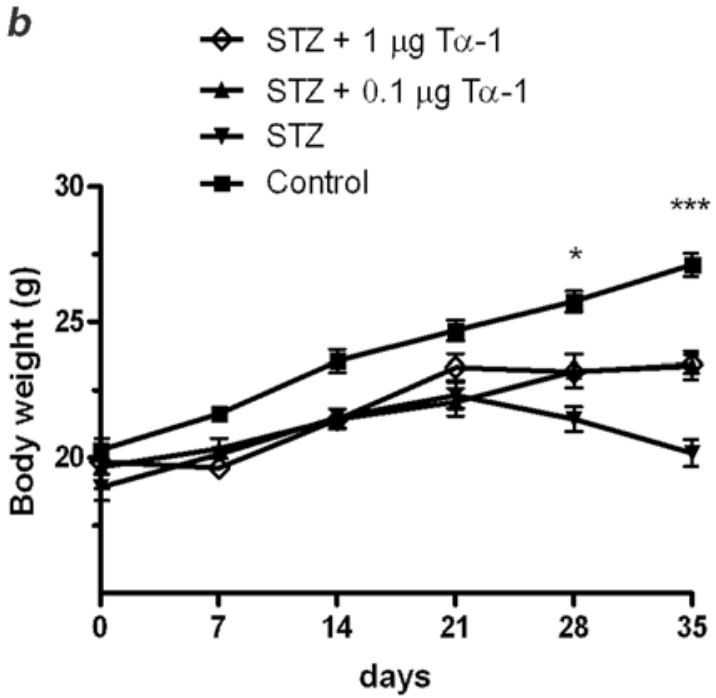

Figure 1. Effect of T $\alpha-1$ treatment on body weight and blood glucose levels of STZ-induced diabetic mice. (a) Blood glucose levels in four groups of mice ( $\mathrm{n}=6 /$ group). Data are expressed as the mean $\pm \mathrm{SEM} .{ }^{*} \mathrm{P}<0.05$ (STZ-treated vs STZ $+1 \mu \mathrm{g} / \mathrm{kg}$ T $\alpha-1$-treated); ${ }^{* *} \mathrm{P}<0.01$ (STZ-treated vs STZ $+1 \mu \mathrm{g} / \mathrm{kg}$ T $\alpha-1$ treated); ${ }^{* * *} \mathrm{P}<0.001$ (STZ-treated vs STZ $+1 \mu \mathrm{g} / \mathrm{kg} \mathrm{T} \alpha$-1-treated). (b) Body weight changes for four groups of mice (n=6/group).

and calculated as $\mu$ moles of $\mathrm{H}_{2} \mathrm{O}_{2}$ consumed $/ \mathrm{min} / \mathrm{mg}$ of protein.

Determination of malondialdehyde (MDA) and glutathione $(G S H)$. An aliquot of $1 \mathrm{ml}$ of the suspension medium was taken from the supernatant obtained after the centrifugation of tissue homogenate $(10 \% \mathrm{w} / \mathrm{v})$ at $10,500 \mathrm{x} \mathrm{g}$ for $15 \mathrm{~min}$. Approximately $0.5 \mathrm{ml}$ of $30 \%$ trichloroacetic acid (TCA) followed by $0.5 \mathrm{ml}$ of $0.8 \%$ thiobarbituric acid (TBA) was then added. The tubes were kept in a shaking water bath for $30 \mathrm{~min}$ at $80^{\circ} \mathrm{C}$. After $30 \mathrm{~min}$ of incubation, the tubes were taken out and kept in ice-cold water for $10 \mathrm{~min}$. These were then centrifuged at $800 \mathrm{x} \mathrm{g}$ for $15 \mathrm{~min}$. The absorbance of the supernatant was read at $540 \mathrm{~nm}$ at room temperature against an appropriate blank. The concentration of MDA was measured from the standard calibration curve prepared by using tetraethoxypropane. Lipid peroxidation was expressed as nmoles of MDA/mg of protein. The GSH level in pancreatic tissue was assayed using a commercial kit (Jianchen) and was expressed as nmoles of GSH/mg of protein.

Aldehyde fuchsin staining. Immediately following dissection, pancreatic tissues were washed with ice-cold saline. They were then fixed with $4 \%$ buffered paraformaldehyde and embedded in paraffin. Sections $(5-\mu \mathrm{m})$ were stained with Gormori's aldehyde fuchsin solution [pararosaniline $(0.5 \mathrm{~g})$, $70 \%$ ethanol $(100 \mathrm{ml})$, paraldehyde $(1 \mathrm{ml})$ and hydrochloric acid $(1 \mathrm{ml})$ ] as described previously (16). Briefly, sections were dewaxed and rehydrated, and then oxidized with Lugol's iodine, decolourised with sodium thiosulphate. Processed sections were stained with aldehyde fuchsin solution and counterstained with haematoxylin and light green/orange $\mathrm{G}$.

Statistical analysis. Quantitative data were expressed as the mean \pm SEM. The Student's t-test was used for pairwise comparisons and one-way ANOVA with Newman-Keuls multiple comparison test for multigroup analyses. Differences were considered significant when probability values were $<0.05$.

\section{Results}

Ta-1 co-administration led to reduced blood glucose levels, partially restored plasma insulin levels and significant improvement in pancreatic morphology in STZ-induced diabetic mice. To investigate the effect of T $\alpha-1$ on the development of diabetes, we co-treated two groups of mice with $\mathrm{T} \alpha-1$ at the doses of 0.1 or $1 \mu \mathrm{g} / \mathrm{kg} /$ day, respectively, for 5 weeks. Fig. 1a shows the effect of T $\alpha-1$ co-treatment on blood glucose levels. Following 5 days of STZ injections, hyperglycemia developed quickly in the STZ-treated but T $\alpha-1$ untreated mice (B); blood glucose rose to $\sim 16.4 \mathrm{mM}$ by day 14 , reached $24.3 \mathrm{mM}$ at day 21 and sustained a relatively stable level up to day 35 , while that of the normoglycemic control (A) remained constant at $<8 \mathrm{mM}$. In contrast, in two groups that were STZ-treated but received T $\alpha-1$ co-treatment at the doses of 0.1 and $1 \mu \mathrm{g} / \mathrm{kg}$, respectively (C and D), blood glucose levels were significantly lower than that of the $B$ group of mice for all the time points assayed (starting from day 14 to day 35). The blood glucose levels for both the C and D groups of mice, however, remained significantly higher than that of the normal mice (A). Despite this, T $\alpha-1$ co-treatment was demonstrated to significantly correct STZ-induced hyperglycemia. Furthermore, these changes in blood glucose were accompanied by corresponding changes in body weight among the mouse groups. At the end of the T $\alpha-1$ treatment, significant weight loss was observed for all STZ-treated mouse groups (B, C and D) (Fig. 1b). However, for the two mouse groups that were STZ-treated but received T $\alpha$ - 1 co-treatment at the doses of 0.1 and $1 \mu \mathrm{g} / \mathrm{kg}$, respectively (C and D), the body weights were significantly higher than that of the $B$ group mice, suggesting overall improvement in metabolism following T $\alpha-1$ administration. 


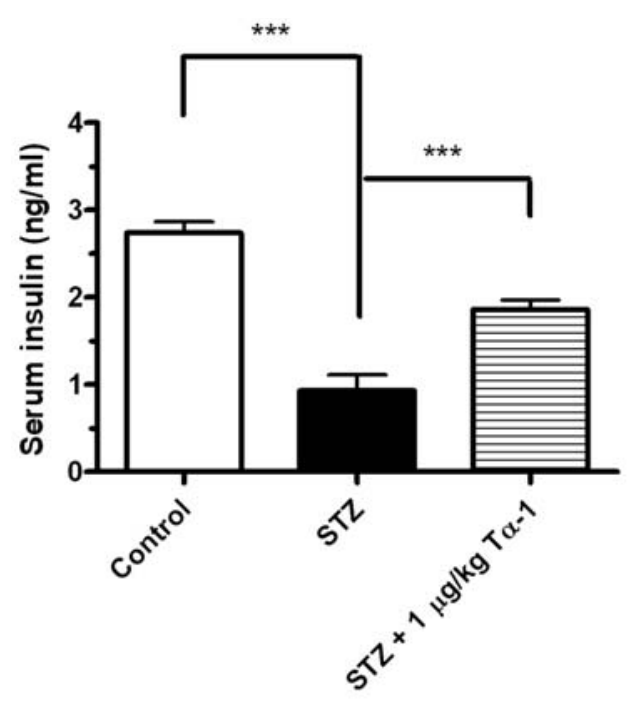

Figure 2. Effect of T $\alpha-1$ treatment on serum insulin levels in STZ-induced diabetic mice. Mouse groups used were normoglycemic control, STZtreated and STZ $+1 \mu \mathrm{g} / \mathrm{kg} \mathrm{T} \alpha-1$-treated, respectively (n=6/group). Data are expressed as the mean \pm SEM. ${ }^{* * *} \mathrm{P}<0.001$.

To assess the impact of $\mathrm{T} \alpha-1$ treatment on insulin secretion, serum insulin levels were assayed in normal, diabetic and $\mathrm{T} \alpha-1$-treated diabetic mice. As shown in Fig. 2, STZ treatment resulted in a significant decrease in serum insulin levels by $66.1 \%$ in STZ-diabetic mice (B) when compared with normoglycemic mice $(0.93 \pm 0.19 \mathrm{ng} / \mathrm{ml}$ for B vs $2.74 \pm 0.13 \mathrm{ng} / \mathrm{ml}$ for $\mathrm{A}, \mathrm{P}<0.001)$. Following co-administration of $1 \mu \mathrm{g} / \mathrm{kg} /$ day $\mathrm{T} \alpha-1$ for 35 days, however, serum insulin levels were partially restored and were nearly 2-fold higher than that of diabetic mice $(1.86 \pm 0.11 \mathrm{ng} / \mathrm{ml}$ for $\mathrm{D}$ vs $0.93 \pm 0.19 \mathrm{ng} / \mathrm{ml}$ for $\mathrm{B}, \mathrm{P}<0.001)$.

To evaluate the effects of T $\alpha-1$ on STZ-induced pancreatic histological damage, we performed aldehyde fuchsin staining on three treatment groups of mice. As shown in Fig. 3, in normal mice, aldehyde fuchsin staining showed typical normal morphology and pancreatic islet shape and size with substantial large number of $ß$ cells (purple-stained). In contrast, significant pancreatitis, islet atrophy, and almost complete loss of $\beta$ cells were found for mice that were STZ-treated but without T $\alpha-1$ co-treatment. Notably, in STZ-treated mice receiving $1 \mu \mathrm{g} /$ $\mathrm{kg} /$ day $\mathrm{T} \alpha-1$ for 35 days, all STZ-induced lesions appeared to be significantly alleviated, which included restoration of pancreatic shapes and sizes and the number of $\beta$ cells and the disappearance of characteristic histological lesions in diabetic mice.

The significant improvement in blood glucose levels, insulin secretion and pancreatic damage conferred by $\mathrm{T} \alpha-1$ co-administration strongly suggest that $\mathrm{T} \alpha-1$ is one of the major components present in the TF5 preparation that mediates the protection against STZ-induced pancreatic lesions and development of T1DM.

Ta-1 co-administration improved pancreatic antioxidative defense in STZ-treated mice. MDA, GSH, SOD and CAT levels for pancreatic tissues following STZ diabetic induction and $\mathrm{T} \alpha-1$ treatment are summarized in Table I. At day 35, pancreatic MDA for mice that were STZ-treated but not T $\alpha-1$ was 1.68 -fold that of the normal controls $(0.39 \pm 0.03 \mathrm{nmol} /$ $\mathrm{mg}$ for $\mathrm{B}$ vs $0.23 \pm 0.01 \mathrm{nmol} / \mathrm{mg}$ for $\mathrm{A} ; \mathrm{P}<0.001)$, indicating greatly increased lipid peroxidation. $\mathrm{T} \alpha-1$ treatment at $1 \mu \mathrm{g} /$ $\mathrm{kg} /$ day for 5 weeks, however, resulted in a significantly lower level of MDA $(0.31 \pm 0.02 \mathrm{nmol} / \mathrm{mg}$ for D vs $0.39 \pm 0.03 \mathrm{nmol} /$ $\mathrm{mg}$ for $\mathrm{B} ; \mathrm{P}<0.05)$. In accordance with the changes in MDA levels, the pancreatic tissue GSH level was dramatically decreased following STZ treatment $(17.19 \pm 2.11 \mathrm{nmol} / \mathrm{mg}$ for B vs $52.93 \pm 3.25 \mathrm{nmol} / \mathrm{mg}$ for $\mathrm{A} ; \mathrm{P}<0.001)$ but was greatly alleviated as a consequence of $\mathrm{T} \alpha-1$ treatment $(32.92 \pm 3.57 \mathrm{nmol} /$ $\mathrm{mg}$ for $\mathrm{D}$ vs $17.19 \pm 2.11 \mathrm{nmol} / \mathrm{mg}$ for $\mathrm{B} ; \mathrm{P}<0.01)$. Furthermore, although not statistically significant, $\mathrm{T} \alpha-1$ treatment to a certain degree restored the activities of both SOD $(17.13 \pm 0.8 \mathrm{U} /$ mg protein for D vs $14.32 \pm 0.85 \mathrm{U} / \mathrm{mg}$ protein for $\mathrm{B}$; $\mathrm{P}<0.05$ with the Student's t-test but $\mathrm{P}>0.05$ with one-way ANOVA) and CAT $(0.7 \pm 0.06 \mathrm{U} / \mathrm{mg}$ protein for D vs $0.42 \pm 0.06 \mathrm{U} / \mathrm{mg}$ protein for $\mathrm{B} ; \mathrm{P}<0.05$ with the Student's t-test but $\mathrm{P}>0.05$ with one-way ANOVA). While T $\alpha-1$ co-treatment to a certain degree improved the above-mentioned antioxidative parameters, the treatment did not completely correct the STZ-induced deterioration in antioxidative capabilities of the pancreatic tissues. Together, these data strongly indicate that T $\alpha-1$ treatment at $1 \mu \mathrm{g} / \mathrm{kg} / \mathrm{day}$ for 5 weeks leads to reduced MDA, increased GSH level and increased activities of both SOD and CAT, suggesting that $\mathrm{T} \alpha-1$ treatment greatly enhances the overall antioxidative capability of pancreatic tissues which might contribute, in part, to its protection against STZinduced pancreatic lesions and diabetes.

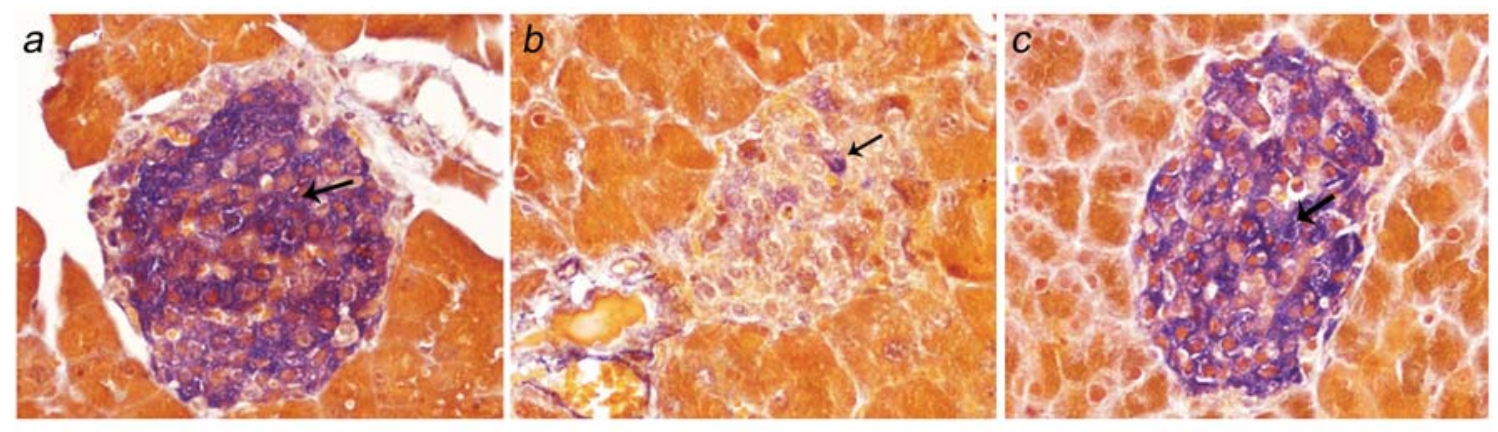

Figure 3. Aldehyde fuchsin staining of pancreatic tissues from three mouse groups. Pancreatic tissues from three mouse groups, i.e., normoglycemic control (a), STZ-treated (b) and STZ $+1 \mu \mathrm{g} / \mathrm{kg} \mathrm{T} \alpha-1$-treated (c), were collected and stained as described. Results are typical for 3 mice/group. Insulin-secreting $\beta$ cells (arrow) were stained purple. Pancreatic $\alpha$ cells and other peripheral cells appear brown-yellow. Original magnification, $\mathrm{x} 400$. 
Table I. Pancreatic superoxide dismutase (SOD) and catalase (CAT) activities and malondialdehyde (MDA) and glutathione (GSH) levels in three groups of mice.

\begin{tabular}{lcccc}
\hline Mouse group & MDA (nmol/mg protein) & GSH (nmol/mg protein) & SOD (U/mg protein) & CAT (U/mg protein) \\
\hline A (n=6) & $0.23 \pm 0.01$ & $52.93 \pm 3.25$ & $26.20 \pm 2.61$ & $1.16 \pm 0.17$ \\
B (n=6) & $0.39 \pm 0.03^{\mathrm{a}}$ & $17.19 \pm 2.11^{\mathrm{a}}$ & $14.32 \pm 0.85^{\mathrm{a}}$ & $0.42 \pm 0.06^{\mathrm{a}}$ \\
$\mathrm{D}(\mathrm{n}=6)$ & $0.31 \pm 0.02^{\mathrm{b}}$ & $32.92 \pm 3.57^{\mathrm{c}}$ & $17.13 \pm 0.80$ & $0.70 \pm 0.06$ \\
\hline
\end{tabular}

Mouse groups used were normoglycemic control (A), STZ-treated (B) and STZ + $1 \mu \mathrm{g} / \mathrm{kg}$ T $\alpha-1$ treated (D), respectively. One-way ANOVA with Newman-Keuls test was used for multiple group analysis. Data was expressed as the mean $\pm \mathrm{SEM}$. ${ }^{\mathrm{a} P}<0.001$ (B vs $\left.\mathrm{A}\right)$; ${ }^{\text {b }}<0.05$ and ${ }^{\mathrm{c}} \mathrm{P}<0.01$ (D vs B).

\section{Discussion}

In this study, we demonstrated that $\mathrm{T} \alpha-1$ co-administration resulted in significant protection against STZ-induced damage to pancreatic tissue, in particular $B$ cells. We further showed that probably due to this $\mathrm{T} \alpha-1$-mediated pancreatic protection, insulin secretion and blood glucose were greatly improved. In a previous study conducted by Tabata et al, CD-1 mice were treated with a crude thymosin preparation TF5 at 10$100 \mu \mathrm{g} / \mathrm{kg} /$ day for $4-5$ weeks demonstrating the protective effects of TF5 against STZ-induced diabetic lesions (12). In our current study, similar experimental conditions were used except that much lower doses of thymosin $(0.1-1 \mu \mathrm{g} / \mathrm{kg} /$ day $\mathrm{T} \alpha-1$ for 5 weeks) were used. Using these much lower doses (100-fold less), however, we demonstrated that they were sufficient to cause similar pancreatic protection as reported by Tabata et al (12) and Yao et al (14). As a matter of fact, in an earlier report, T $\alpha-1$ was shown to be 10 - to 1000 -fold more active than TF5 (17). Thus, our results strongly suggest that $\mathrm{T} \alpha-1$ is a critical thymosin molecule in TF5 which plays the most important role in protecting animals from toxininduced pancreatic damage and the development of T1DM.

The immunomodulatory and anti-inflammatory effects of $\mathrm{T} \alpha-1$ have been studied intensively $(5,18)$. T $\alpha-1$ is believed to be able to modulate the immune system by augmenting $\mathrm{T}$ cell function. It plays an important paracrine role in $\mathrm{T}$ cell differentiation and participates in the regulation of mature $\mathrm{T}$ lymphocyte proliferation in conjunction with mitogen and interleukin 1 (IL-1) through promoting interleukin 2 (IL-2) production and IL-2 receptor expression by $\mathrm{T}$ lymphocytes (19). Furthermore, TF5 or T $\alpha-1$ in vivo or in vitro also has been shown to promote $\mathrm{T}$ lymphocyte maturation or improve the immune response in chemical toxin-induced T1DM models (8-10,12-14). Paradoxically, T1DM is thought to be an autoimmune disease involving $\mathrm{T}$ cell-mediated destruction of pancreatic $B$ cells. It thus raises an intriguing question whether T $\alpha-1$ treatment protects pancreatic $\beta$ cells rather than activating $\mathrm{T}$ lymphocytes to exacerbate pancreatic $B$ cell damage. A recent study by Yao et al (14) suggested that one of the major effects of T $\alpha-1$ treatment is to lead to a subtype switch between $\mathrm{CD}^{+} / \mathrm{CD}^{+} / \mathrm{CD}^{+} \mathrm{T}$ lymphocytes. It might be that such a $\mathrm{T}$ cell subtype switch results in a change in the ratio between suppressor $\mathrm{T}$ cells and cytotoxic $\mathrm{T}$ cells (20) which provides part of the protection to the pancreatic tissue. In spite of this, the activation and subtype switch of
T lymphocytes alone might not be sufficient to completely explain the overall protective effects of TF5 or T $\alpha-1$. Apparently, the actual mechanisms involved might be much more complicated and might include mechanisms involved in angiogenesis $(21,22)$, wound healing (21) and oxidative defense.

Oxidative stress has been implicated in the pathophysiology of various diseases including diabetes mellitus (23-25). Immune cells, particularly macrophages and T cells, are cytotoxic to islet $B$ cells, in part, by generating cytokines and free radicals. Pancreatic $\beta$ cells are very susceptible to oxidative damages because of their low antioxidative capacity (26). 3 cell injury in animals has been found to be provoked by chemicals that increase cellular oxidative stress, which include STZ and alloxan. During STZ metabolism, various toxic intermediates are produced, including methyl radicals, reactive oxygen species (ROS) and nitric oxide (NO) (27-29).

A number of studies have shown that thymosins might be involved in antioxidative defense. For instance, Li et al (30) reported that in the liver of young adult thymectomized rats, MDA, a metabolite of lipid peroxidation, was significantly increased. In these thymectomized rats, both the activities of SOD and the hepatic content of GSH were also significantly decreased. Administration of thymosins to these animals, on the other hand, led to decreased MDA levels and increased GSH content in the liver. Moreover, Lau et al also found that thymosin treatment protected vascular endothelial cells from oxidative injury (31). Together, these results suggest that, in addition to their well-established immunomodulatory roles, thymosins might also play important roles in antioxidative defense. For T $\alpha-1$, Ademoglu et al (32) reported that plasma and erythrocyte MDA levels were significantly decreased in T $\alpha$-1-injected rats. Armutcu et al (33) reported that liver MDA levels were significantly decreased after $\mathrm{T} \alpha-1$ treatment in high fructose-induced steatohepatitis rats. In addition, T $\alpha-1$ was also found to be able to protect liver and aorta from oxidative damage in atherosclerotic rabbits through increasing liver and aorta GSH levels and decreasing liver and aorta MDA levels (34). T $\alpha-1$, therefore, might confer pancreatic protection against toxin-induced $B$ cell damage and the development of hyperglycemia, in part, by improving cellular defense against oxidative stress.

In our study, pancreatic MDA levels were greatly increased while GSH levels were greatly decreased in STZ-induced diabetic mice. Additionally, the activities of two major 
enzymes for antioxidative defense, SOD and CAT, were greatly reduced. STZ treatment, therefore, caused severe loss of antioxidative capabilities and increased lipid peroxidation. These lesions, however, were significantly ameliorated in mice which received both $\mathrm{STZ}$ and $\mathrm{T} \alpha-1$. As a consequence of co-administration of $1 \mu \mathrm{g} / \mathrm{kg} /$ day $\mathrm{T} \alpha-1$ for 5 weeks, pancreatic MDA levels were significantly reduced and GSH levels were significantly increased. Furthermore, although not statistically significant, improvement in enzyme activities were also observed for SOD and CAT. While these data are consistent with previous studies showing the antioxidative roles of $\mathrm{T} \alpha-1$ in a number of other tissues (32-34), our results indicate that in vivo administration of $\mathrm{T} \alpha-1$ greatly enhances the antioxidative capability of $\beta$ cells and pancreatic tissues in STZ-induced diabetic mice, suggesting that indeed the pancreatic protection provided by $\mathrm{T} \alpha-1$ is, in part, mediated via enhanced pancreatic antioxidative defense.

\section{Acknowledgements}

This work was supported in part by the National Science Foundation of China grant no. 30770490 and 973 Program of China grant no. 2009CB941601.

\section{References}

1. Goldstein AL and Badamchian M: Thymosins: chemistry and biological properties in health and disease. Expert Opin Biol Ther 4: 559-573, 2004.

2. Hannappel E and Huff T: The thymosins. Prothymosin alpha, parathymosin, and beta-thymosins: structure and function. Vitam Horm 66: 257-296, 2003.

3. Segade F and Gomez-Marquez J: Prothymosin alpha. Int J Biochem Cell Biol 31: 1243-1248, 1999.

4. Goldstein AL, Hannappel E and Kleinman HK: Thymosin beta4: actin-sequestering protein moonlights to repair injured tissues. Trends Mol Med 11: 421-429, 2005.

5. Ancell CD, Phipps J and Young L: Thymosin alpha-1. Am J Health Syst Pharm 58: 879-885, 2001.

6. Billich A: Thymosin alpha1. SciClone Pharmaceuticals. Curr Opin Investig Drugs 3: 698-707, 2002.

7. Garaci E, Favalli C, Pica F, Sinibaldi VP, Palamara AT, Matteucci C, Pierimarchi P, Serafino A, Mastino A, Bistoni F, Romani L and Rasi G: Thymosin alpha 1: from bench to bedside. Ann NY Acad Sci 1112: 225-234, 2007.

8. Salvin SB and Tanner EP: Resistance and susceptibility to infection in inbred murine strains. III. Effect of thymosin on cellular immune responses of alloxan diabetic mice. Clin Exp Immunol 55: 133-139, 1984.

9. Okimoto T, Kinoshita Y, Hato F, Toyokawa T, Kimura S and Kinoshita H: Effects of thymosin on soybean lectin responsiveness of thymic small lymphocyte subsets from streptozotocininduced diabetic rats. Cell Mol Biol 34: 465-472, 1988.

10. Winter WE, Robbins V, Elder M, Barrett D, Martin N and Maclaren NK: Thymosin and the spontaneously diabetic BB rat. Autoimmunity 1: 115-123, 1988.

11. Strausser HR: Use of thymosin as an anti-diabetes and antihypertensive disease agent. US Patent $\# 4,444,757,1984$.

12. Tabata T, Kinoshita Y, Fujii S, Hato F, Toyokawa T, Kimura S and Morii $\mathrm{H}$ : Protection by thymosin fraction 5 from streptozotocin-induced diabetes in mice. Cell Mol Biol 35: 121-127, 1989.

13. Mizina TI: Hypoglycemic effect of thymosine in an animal experiment. Vopr Med Khim 35: 80-82, 1989.
14. Yao W, Zhu Q, Yuan Y, Qiao M, Zhang Y and Zhai Z: Thymosin alpha 1 improves severe acute pancreatitis in rats via regulation of peripheral $\mathrm{T}$ cell number and cytokine serum level. J Gastroenterol Hepatol 22: 1866-1871, 2007.

15. Sinha AK: Colorimetric assay of catalase. Anal Biochem 47: 389-394, 1972.

16. Jennings BM: Aldehyde-fuchsin staining applied to sections for demonstrating pituitary and pancreatic beta cells. J Histochem Cytochem 13: 328-333, 1965.

17. Low TL, Thurman GB, McAdoo M, McClure J, Rossio JL, Naylor PH and Goldstein AL: The chemistry and biology of thymosin. I. Isolation, characterization, and biological activities of thymosin alpha1 and polypeptide beta1 from calf thymus. J Biol Chem 254: 981-986, 1979.

18. Romani L, Bistoni F, Montagnoli C, Gaziano R, Bozza S, Bonifazi P, Zelante T, Moretti S, Rasi G, Garaci E and Puccetti P: Thymosin alpha1: an endogenous regulator of inflammation, immunity, and tolerance. Ann NY Acad Sci 1112: 326-338, 2007.

19. Sztein MB and Serrate SA: Characterization of the immunoregulatory properties of thymosin alpha 1 on interleukin-2 production and interleukin-2 receptor expression in normal human lymphocytes. Int J Immunopharmacol 11: 789-800, 1989.

20. Wang SH, Chen G and Zhang K: Effects of thymosin and insulin on suppressor T cell in type 1 diabetes. Diabetes Res 19: 21-29, 1992.

21. Malinda KM, Sidhu GS, Banaudha KK, Gaddipati JP, Maheshwari RK, Goldstein AL and Kleinman HK: Thymosin alpha 1 stimulates endothelial cell migration, angiogenesis, and wound healing. J Immunol 160: 1001-1006, 1998.

22. Koutrafouri V, Leondiadis L, Avgoustakis K, Livaniou E, Czarnecki J, Ithakissios DS and Evangelatos GP: Effect of thymosin peptides on the chick chorioallantoic membrane angiogenesis model. Biochim Biophys Acta 1568: 60-66, 2001.

23. Kakkar R, Kalra J, Mantha SV and Prasad K: Lipid peroxidation and activity of antioxidant enzymes in diabetic rats. Mol Cell Biochem 151: 113-119, 1995.

24. West IC: Radicals and oxidative stress in diabetes. Diabet Med 17: 171-180, 2000 .

25. Wolff SP: Diabetes mellitus and free radicals. Free radicals, transition metals and oxidative stress in the aetiology of diabetes mellitus and complications. Br Med Bull 49: 642-652, 1993.

26. Kajimoto $\mathrm{Y}$ and Kaneto $\mathrm{H}$ : Role of oxidative stress in pancreatic beta-cell dysfunction. Ann NY Acad Sci 1011: 168-176, 2004.

27. Peschke E, Ebelt H, Bromme HJ and Peschke D: 'Classical' and 'new' diabetogens - comparison of their effects on isolated rat pancreatic islets in vitro. Cell Mol Life Sci 57: 158-164, 2000.

28. Evans JS, Gerritsen GC, Mann KM and Owen SP: Antitumor and hyperglycemic activity of streptozotocin (NSC-37917) and its cofactor, U-15,774. Cancer Chemother Rep 48: 1-6, 1965.

29. Gonzalez E, Jawerbaum A, Sinner D, Pustovrh C, White V, Capobianco E, Xaus C, Peralta C and Rosello-Catafau J: Streptozotocin-pancreatic damage in the rat: modulatory effect of 15-deoxy delta12,14-prostaglandin $\mathrm{j}(2)$ on nitridergic and prostanoid pathway. Nitric Oxide 6: 214-220, 2002.

30. Li L, Zhou JH, Xing ST and Lau BH: Thymus-neuroendocrineliver pathway. Med Hypotheses 41: 470-472, 1993.

31. Lau BH, Li L and Yoon P: Thymic peptide protects vascular endothelial cells from hydrogen peroxide-induced oxidant injury. Life Sci 52: 1787-1796, 1993.

32. Ademoglu E, Gokkusu C and Oz B: Thymosin alpha-1: evidence for an antiatherogenic effect. Ann Nutr Metab 42: 283-289, 1998.

33. Armutcu F, Coskun O, Gurel A, Kanter M, Can M, Ucar F and Unalacak M: Thymosin alpha 1 attenuates lipid peroxidation and improves fructose-induced steatohepatitis in rats. Clin Biochem 38: 540-547, 2005.

34. Gokkusu C, Ademoglu E, Turkoglu UM, Oz H and Oz F: Thymosin alpha 1 protects liver and aorta from oxidative damage in atherosclerotic rabbits. Life Sci 59: 1059-1067, 1996. 